\title{
界面活性剂無添加系エマルションの新しい展開 New Aspects of Surfactant-free emulsion
}

\begin{tabular}{|c|c|}
\hline $\begin{array}{r}\text { 酒井俊郎 } \\
\text { 東京理科大学理工学部 } \\
\text { 278-8510 } \\
\text { 千葉県野田市山崎 } 2641 \\
\text { Toshio SAKAI } \\
\text { Soshio SAKAI } \\
\text { Faculty of Science and Technology, } \\
\text { Science University of Tokyo } \\
2641 \text { Yamazaki, Noda, } \\
\text { Chiba 278-8510 }\end{array}$ & $\begin{array}{l}\text { 加茂川恵司 } \\
\text { 東京理科大学界面科学研究所 } \\
\text { T } 278-8510 \\
\text { 千葉県野田市山崎 } 2641 \\
\text { Keiji KAMOGAWA } \\
\text { Institute of Colloid and Interface } \\
\text { Science, Science University of Tokyo } \\
2641 \text { Yamazaki, Noda, } \\
\text { Chiba 278-8510 }\end{array}$ \\
\hline $\begin{array}{r}\text { 酒井秀樹 } \\
\text { 東京理科大学理工学部 } \\
\text { 東京理科大学界面科学研究所 } \\
\text { 厂 278-8510 千葉県野田市山崎 } 2641\end{array}$ & $\begin{array}{l}\text { 阿部正彦 } \\
\text { 東京理科大学理工学部 } \\
\text { 東京理科大学界面科学研究所 } \\
\text { T 278-8510 千葉県野田市山崎 } 2641\end{array}$ \\
\hline $\begin{array}{r}\text { Hideki SAKAI } \\
\text { Faculty of Science and Technology, } \\
\text { Science University of Tokyo } \\
\text { Institute of Colloid and Interface } \\
\text { Science, Science University of Tokyo } \\
2641 \text { Yamazaki, Noda, Chiba } 278-8510\end{array}$ & $\begin{array}{l}\text { Masahiko ABE } \\
\text { Faculty of Science and Technology, } \\
\text { Science University of Tokyo } \\
\text { Institute of Colloid and Interface } \\
\text { Science, Science University of Tokyo } \\
2641 \text { Yamazaki, Noda, Chiba 278-8510 }\end{array}$ \\
\hline
\end{tabular}

\begin{abstract}
If one can prepare small droplets in the form of emulsion or microemulsion without addition of surfactant, the droplets would have a clear, discontinuous interface as well as highly hydrophobic interior and show properties different from those of droplets in ordinary microemulsions. From an energetic viewpoint, such surfactant-free droplets should be thermodynamically unstable and can be prepared only transiently in solution, either by nucleation of supersaturated molecules (solute) or by enforced dispersion of organic liquid (solute) in water. Surfactant-free emulsion is the simplest system of liquid/liquid dispersions, which can help us clarify the evolution and growth processes, stability mechanisms, and determination of droplet sizes in emulsion systems. In this review, the discrete size distribution of oil droplets, the relationship between formation of fine droplets (and/or dispersion stability) and viscosity (and/or vapor pressure) of oils, difference of the growth processes between S class droplets (below $100 \mathrm{~nm}$ in diameter) and M class droplets (above $100 \mathrm{~nm}$ in diameter), influence of structure of oil molecules on stability, and dispersion stability of oil droplets by addition of another oil are discussed.
\end{abstract}

Key words: surfactant-free emulsion (SFE), ulrtasonication, discrete size distribution, freeze fracture electron microscopy (FFEM), stability, coemulsifier

\section{1. はじめに}

我々は，近年界面活性剂無添加系エマルション（Surfactant-free emulsion; SFE）の調製を試み，その溶液物 性を検討している。界面活性剤無添加系エマルションの 最大の利点は, 系がシンプルなところである。通常言わ れているエマルションとは, 水と油のような均一に溶解 しない二種類の液体の一方が微粒子（分散質）となっ て, 他方の液体（分散媒）中に分散している系を指し, 分散質表面には界面活性剂分子などが吸着している。エ
マルションは熱力学的に不安定な系であるため, さまざ まな不安定化機構, 例えば, 重力による分離（比重差）, 凝集, 合一, オストワルド熟成などにより, 時間が経過 すると必然的に崩壊する ${ }^{1-5)}$ 。このようなエマルション の複雑な不安定機構を解明するために，これまでに様々 なアプローチがなされてきているが(6)-10)，界面活性剤な どの安定化郕が共存するために液/液分散系における液 滴の分散安定性の理解を分かりにくくしているのが現状 である。また, エマルションの本来の目的は, 水あるい は油だけの一液相では決して得られない高付加価值を有 
する系を作り出すことであり，乳化剂を添加することが 目的ではない。さらに，エマルション本来の姿である分 散相や分散媒の特性は, 界面活性剂自身の乳化作用に依 存するあまり，見落とされている可能性もある。

そこで，シンプルな系である界面活性剤無添加系エマ ルションの物性を十分に理解することができれば，エマ ルション溶液などの液/液分散系の本質の解明に大いに 寄与できるものと考えられる。また，工学的な興味とし ては, 界面活性剂無添加系エマルションが持つ高い疎水 環境を微小反応場とする応用があげられる。従来より， 界面活性剂ミセルの可溶化特性を生かした乳化重合や逆 ミセルのウォータープールを反応場とした無機超微粒子 の調製などが報告されているが，このようにして調製さ れた微粒子の表面には，本来必要ではない界面活性剤分 子が吸着している。しかし実用に際しては吸着した界面 活性剂分子の除去が不可欠であるけれども，それほど容 易ではなく ${ }^{11)}$ ，場合によっては微粒子表面に取り込まれ てしまう場合もある。その点，純粋な疎水環境や親水環 境を有する油滴あるいは水滴を提供する界面活性剤無添 加系エマルションを利用できれば, 清浄表面を有する微 粒子を得ることが可能になるであろう。さらに，分散質 が固体であるサスペンションの場合, 概して微粒子の大 きさが極端に小さくなると, 微粒子としての特性がより 顕著に現れるようになり, 通常の固体では認められない 特異な性質を発現する。例えば，無機固体粒子の場合， 約 $5 \mathrm{~nm}$ 以下の大きさになると融点が降下したり, 触媒 活性や化学反応性が急激に高まったり, 特異な反応選択 性を示したりする。また，電子構造にも変化を生じた り, 新しい機能の発現も期待されている ${ }^{11)}$ 。このような 固体の微粒子化による特異性の発現は液体微粒子におい ても起こり得るのだろうか。

界面活性剤無添加系エマルションに関する総説 ${ }^{12)-14}$ は これまでにも書いてきたが，その後新しい事実も見出し たのでなるべく重複を避けながら述べることにする。

\section{2. 離散的粒子径分布の出現と不連続成長}

まず，エマルションを調製した際に安定性が悪いと言 われている炭化水素鎖長が 6 の油であり水よりも比重が 軽いベンゼン, $\mathrm{n}$-ヘキサン, シクロヘキサン, 水の比重 より重いフルオロベンゼンを水中で強力な外的因子を印 加した場合（超音波照射）の油滴粒子径の経時変化を動 的光散乱法（DLS）を用いて見てみることにする ${ }^{15)}$ 。

代表として, ベンゼン $\left(30 \mathrm{mM} ; 25^{\circ} \mathrm{C} に\right.$ 扔ける飽和溶 解度は $23 \mathrm{mM}$ であるので，この濃度は若干過飽和であ る）を水に添加して超音波を短時間（2 分間）照射して みると, 透明な溶液が得られる。その溶液内部の様子を

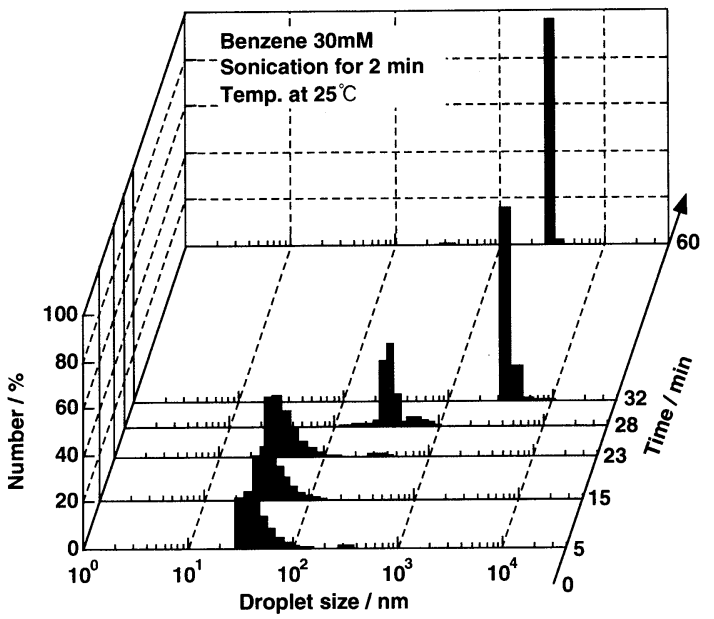

Fig.1 Size distributions at various elapsed times of benzene droplets at $25^{\circ} \mathrm{C}$ measured by dynamic light scattering (Sub-micron particle analyzer system 4700: Malvern Instrument Co.). Benzene concentration; $30 \mathrm{mM}$. Ultrasonic treatment time 2 min.

動的光散乱装置で測定してみると（Fig. 1)，分散の初期 段階では主として数十 $\mathrm{nm}$ 径（Sクラス）のベンゼン粒 子が多数存在し, 少数の数百 $\mathrm{nm}$ 径 (Mクラス) を有す る粒子が観測される。約 20 分が経過すると, S クラス の粒子数が減少して，M クラスの粒子数が増加する。最 終的には数千 $\mathrm{nm}$ 径（L クラス）を有する油滴へと粒子 径は成長する。さらに, 添加濃度を $40 \mathrm{mM}$ まで増加さ せて同様な操作を行うと, 白濁した溶液が得られる。こ の場合も粒子径分布はやはり単一ピークではなく M ク ラスと L クラスの 2 つのピークが共存する離散的な分布 を示す（ただし，超音波処理時間を長くすると（例え ば，8分間)，Sクラスのベンゼン滴を調製することがで きる)。ただしこの場合も，時間が経過すると，Mクラ ス粒子の数が減少し, 最終的には L クラス油滴へと成長 し，粒子径はやはり連続的ではなく離散的に成長する。 そこで, 油の種類をフルオロベンゼン, $\mathrm{n}-$ ヘキサン, シ クロヘキサンに替えてみると (Fig. 2), 超音波照射直後 では油滴の粒子径分布はやはり単一ピークではなく, 飛 び飛びの值を示し（離散的であり）, また, 粒子径の成 長過程においても離散的な傾向になる（なお，この傾向 は攪拌機を高速回転型ホモジナイザーに代えた場合も同 様である $\left.{ }^{15)}\right)$ 。その油滴の粒子径の成長過程がすべて凝 集によるものとすると, 最小粒子（粒子径 $\mathrm{r}_{1}$ ) が特定の 数だけ集まって二次粒子（粒子径 $\mathrm{r}_{2}$ ）を形成し，さらに その粒子が特定の数だけ集まって三次粒子（粒子径 $\mathrm{r}_{3}$ ) を形成する（Fig. 3)。例えば, ベンゼンの場合, 第 1 段 階において約 125 個の最小粒子が集まって二次粒子を形 成し，第 2 段階において約 1000 個の二次粒子が集まっ 


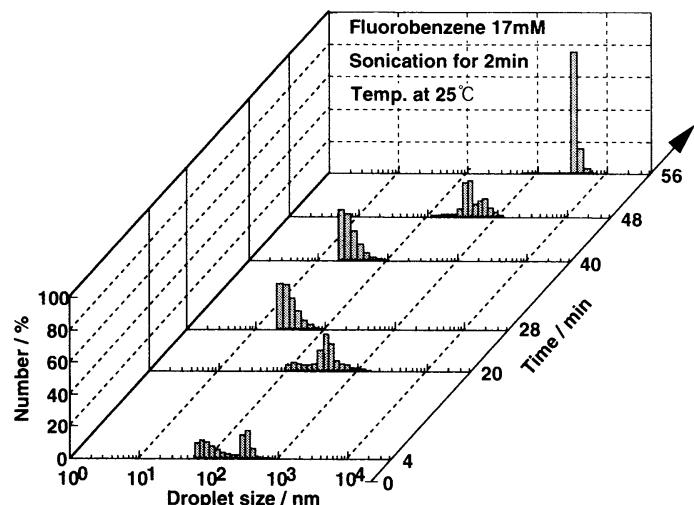

(a)

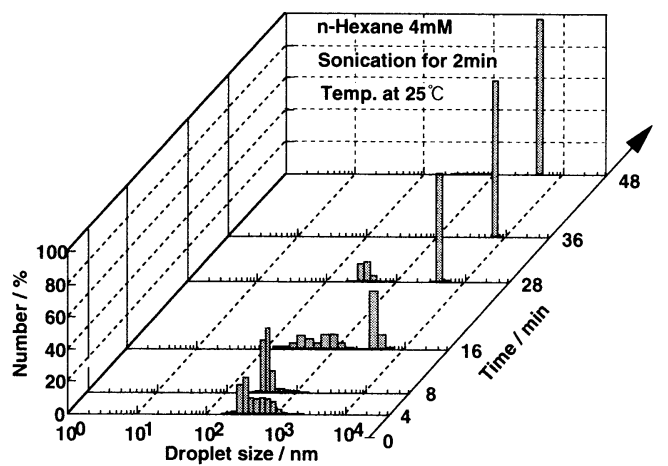

(b)

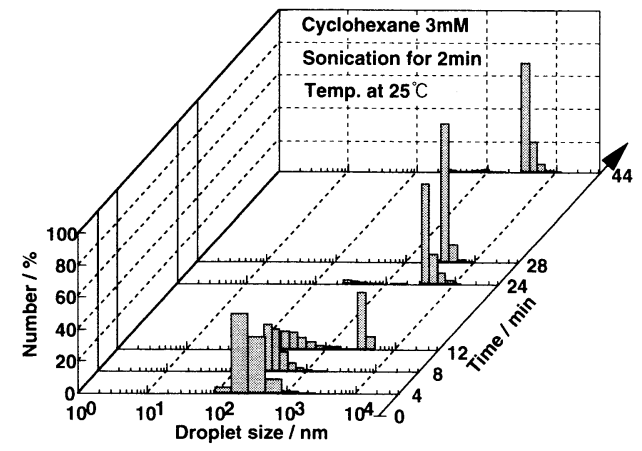

(c)

Fig.2 Size distributions at various elapsed times of (a) fluorobenzene, (b) n-hexane, and (c) cyclohexane droplets at $25^{\circ} \mathrm{C}$ measured by dynamic light scattering (Sub-micron particle analyzer system 4700: Malvern Instrument Co.) after ultrasonication. Concentration of oils: (a) fluorobenzene; $17 \mathrm{mM}$, (b) n-hexane; $4 \mathrm{mM}$ and (c) cyclohexane; $3 \mathrm{mM}$. Ultrasonic treatment time $2 \mathrm{~min}$.

て三次粒子を形成していることになる。このような段階 的な粒子の成長プロセスは, 油滴が㠜集して得られるそ れぞれの油滴内部の圧力（ラプラス圧）の総和が油と水 との界面張力（界面自由エネルギー）を上回ったときに 起こるものと考えられる。また，第 2 段階においては, Young と Laplace ${ }^{1)}{ }^{16)}$ によって提唱された界面の圧力差 $\Delta \mathrm{P}$ (内部圧）より明らかなように, 油滴半径が大きく なると内部圧は逆に小さくなるので, 油と水の界面張力

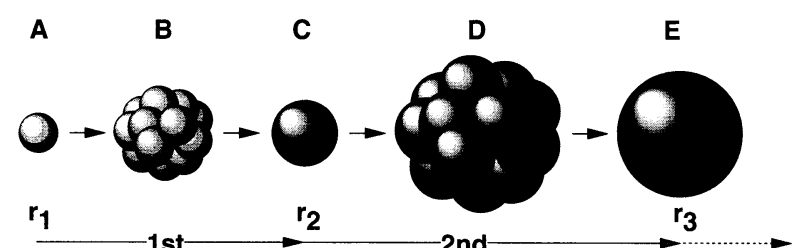

Fig.3 Schematic view of discrete size distribution and growth model of oil droplets. Oil droplets grow from fine class $\operatorname{droplet}(\mathrm{A} \sim \mathrm{B})$ to middle one $(\mathrm{B} \sim \mathrm{C})$, next to visible one $(\mathrm{C} \sim \mathrm{E})$, in which $\mathrm{A}, \mathrm{C}$ and $\mathrm{E}$ are fundamental particles of each class and B, D are their aggregates. $\mathrm{A}$ and $\mathrm{C}$ droplets grow up to $\mathrm{B}$ and $\mathrm{D}$ aggregates within each class, respectively. $\mathrm{B}$ and $\mathrm{D}$ aggregates are fused to generate one $\mathrm{C}$ and $\mathrm{E}$ fundamental droplet of the upper classes, respectively.

を上回るために必要な液滴の数はより多くなることで理 解できる。

$\Delta \mathrm{P}=2 \gamma / \mathrm{r}$

ここで, $\gamma$ は界面張力, $\mathrm{r}$ は油滴の半径である。

次に，粒子径に及ぼす油の疎水性の影響を検討するた めに，飽和炭化水素類の炭素鎖長を増加させて同様の検 討をしてみた（Fig. 4)。Fig. 4 から明らかなように，炭 化水素鎖長の増加に伴い初期粒子径は減少し, 同時にそ の粒子径の経時安定性も向上している。ちなみに，炭素 数 16 のヘキサデカンを用いた場合には, 約 3 日間 S ク ラスの油滴を観測することができた ${ }^{17)}$ 。また，油の種 類, 初期粒子径, 成長過程を分類すると, Table 1 のよ

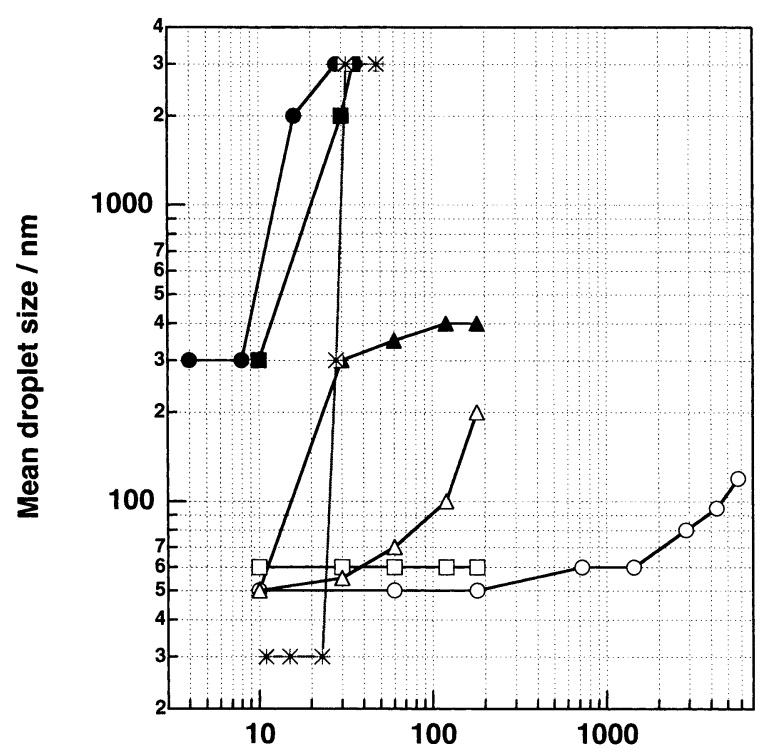

Fig.4 Temporal changes of mean droplet size as a function of time for alkane series and benzene; $30 \mathrm{mM}(*)$. n-Hexane; $3 \mathrm{mM}(\mathbf{O})$, n-octane; $1 \mathrm{mM}(\boldsymbol{\square})$, n-decane; 1 $\mathrm{mM}(\boldsymbol{\Delta})$, n-dodecane; $1 \mathrm{mM}(\Delta)$, n-tetradecane; $1 \mathrm{mM}$ $(\square)$, and n-hexadecane; $1 \mathrm{mM}(\bigcirc)$. 
Table 1 Types of hydrophobic oil droplets.

\begin{tabular}{|c|c|c|c|}
\hline & $\begin{array}{c}{[\mathrm{A}]} \\
\mathrm{n} \text {-hexane type }\end{array}$ & $\begin{array}{c}{[\mathrm{B}]} \\
\mathrm{n} \text {-hexadecane type }\end{array}$ & $\begin{array}{c}{[\mathrm{C}]} \\
\text { benzene type }\end{array}$ \\
\hline Solubility & As low as $1 \mathrm{mM}$ & Quite lower & Very low \\
\hline Viscosity & Very low $23 \mathrm{mM}$ \\
\hline Interfacial tension & $\sim 50 \mathrm{mN} / \mathrm{m}$ & medium & $25-33 \mathrm{mN} / \mathrm{m}$ \\
\hline$\gamma / \eta$ & large & small $\mathrm{mN} / \mathrm{m}$ & small \\
\hline Initial droplets size & $200-300 \mathrm{~nm}$ & $90-100 \mathrm{~nm}$ & $30-50 \mathrm{~nm}$ \\
\hline Growing & Fast M to L change & Slow $\mathrm{S}$ to $\mathrm{M}$ change & Fast $\mathrm{S}$ to M change \\
\hline
\end{tabular}

うな 3 つのタイプに大別できる。

タイプ $(\mathrm{A})$ : ヘキサンやオクタンのような炭化水素鎖 長の短い油は, M クラスから L クラスへ速や かに成長する。

タイプ (B)：ヘキサデカンのような炭化水素鎖長の長い 油は，Sクラスから M クラスへ緩やかに成長 する。

タイプ $(\mathrm{C})$ : ベンゼンのような芳香族炭化水素は, S ク ラス，M クラス，Lクラスへと速やかに成長す る。

さらに，油を代えて不飽和炭化水素類である 1-デセ ンや 1 -ヘキサデセンの場合 ${ }^{18)}$ を見てみると，前述の飽和 炭化水素類よりも分散安定性は劣り, また分岐のある飽 和炭化水素であるスクワランを用いた場合 ${ }^{18)}$ には（Fig. 5), 数十 $\mathrm{nm}$ の極めて小さい粒子径が少なくとも 3 日間 存在できることが分かった。

\section{3. 油の微細化や安定性に及ぼす油の粘性と蒸気圧の影 響}

以上述べてきたように，初期粒子径，粒子径の維持 (安定性), 成長過程は油の種類により特徴的な挙動を示 すことが分かった。そこで，油滴の生成や成長過程を油 の物性ならびに水との関係から検討してみることにす $ろ^{12,14), 18)}$ 。

炭素数 6 から 16 までの偶数のアルカンおよびベンゼ ン, シクロヘキサン, フルオロベンゼンの物性と油滴の 成長パターンを Table 2 に示す ${ }^{12), 18)}$ 。物性を比較してみ ると, 油/水の界面張力は炭化水素鎖長が増加してもほ

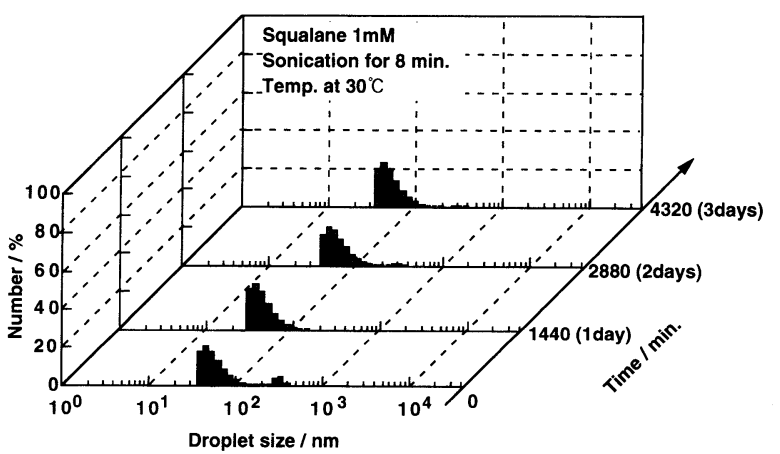

Fig.5 Size distributions at various elapsed times of squalane droplets at $30^{\circ} \mathrm{C}$ measured by dynamic light scattering method. Squalane concentration is $1 \mathrm{mM}$. Sonication time is $8 \mathrm{~min}$.

とんど違いはなく約 $50 \mathrm{mN} / \mathrm{m}$ であったが，粘度および 蒸気圧は大きく違っている。炭素数 6 と 16 を比べた場 合, 粘度では約 10 倍, 蒸気圧では約 $1 / 10^{5}$ 倍違ってい る。このことから, 粘度と蒸気圧は油滴の安定性や粒子 の大きさを決定する重要なファクターであることが示唆 される。

タイプ $(\mathrm{A})$ の油：炭化水素鎖長の短いヘキサンやオクタ ンのような油は, 粘度が低いため水中に分散さ せるのは容易であるが，分子拡散が起こりやす い（蒸気圧が大きい）ので分散安定性に劣る。 ヘキサンのような極めて粘度の小さな油は, か なり大きな蒸気圧（ヘキサデカンの約 $10^{5}$ 倍） を持つため，その状態（小粒子）を維持できず に速やかに大粒子へと成長する。また，溶解度 が極めて小さいため, 分子状態で水中に存在す ることができない。そのため $\mathrm{M}$ クラス以上の油 
Table 2 Evolition pattern and stability of fine particle.

\begin{tabular}{|c|c|c|c|c|c|c|c|c|c|c|c|}
\hline & \multirow{2}{*}{$\begin{array}{c}\text { Molecular } \\
\text { formula }\end{array}$} & \multirow[b]{2}{*}{ M.W. } & \multirow[b]{2}{*}{ m.p. $/^{\circ} \mathrm{C}$} & \multirow[b]{2}{*}{ b.p. $/{ }^{\circ} \mathrm{C}$} & \multirow{2}{*}{$\begin{array}{l}\text { Density } \\
\left(\mathrm{g} / \mathrm{cm}^{3}\right)\end{array}$} & \multirow{2}{*}{$\begin{array}{l}\text { Surface } \\
\text { tension }^{\text {b) }} \\
(\mathrm{mN} / \mathrm{m})\end{array}$} & \multirow{2}{*}{$\begin{array}{c}\text { Interfacial } \\
\text { tension }^{\text {a) }} \\
(\mathrm{mN} / \mathrm{m})\end{array}$} & \multirow{2}{*}{$\begin{array}{l}\text { Viscosity }^{c} \\
/ \mathrm{mPa} \mathrm{s}\end{array}$} & \multirow{2}{*}{$\begin{array}{c}\text { Vapor } \\
\text { pressure }^{\text {b) }} \\
/ \mathrm{mNm}^{-2}\end{array}$} & \multicolumn{2}{|c|}{ Results } \\
\hline & & & & & & & & & & $\begin{array}{c}\text { Evolution } \\
\text { pattern }\end{array}$ & $\begin{array}{l}\text { Stabilitty of } \\
\text { fine paticle }\end{array}$ \\
\hline Water & $\mathrm{H}_{2} \mathrm{O}$ & 18.02 & 0 & 100 & 0.99705 & 72.59 & - & 0.7973 & $3.1673 \times 10^{6}$ & - & - \\
\hline Benzene & $\mathrm{C}_{6} \mathrm{H}_{6}$ & 78.11 & 5.533 & 80.100 & 0.87372 & 28.24 & 35.0 & 0.564 & $1.2689 \times 10^{7}$ & {$[C]^{\text {b)d e) }}$} & $\sim 20 \min ^{\mathrm{b}) \mathrm{d} \mathrm{e})}$ \\
\hline Fluorobenzen & $\mathrm{C}_{6} \mathrm{H}_{5} \mathrm{~F}$ & 96.10 & -42.22 & 84.734 & 1.0183 & 26.66 & - & $0.577\left(19^{\circ} \mathrm{C}\right)$ & $1.0199 \times 10^{7}$ & {$[C]^{\mathrm{b}) \mathrm{d})}$} & $\sim 40 \min ^{\mathrm{b}) \mathrm{d}}$ \\
\hline Cyclohexane & $\mathrm{C}_{6} \mathrm{H}_{12}$ & 84.16 & 6.541 & 80.719 & 0.77853 & 24.65 & 50.59 & 0.825 & $1.3009 \times 10^{7}$ & {$[\mathrm{~A}]^{\mathrm{b}) \mathrm{d})}$} & $0^{\mathrm{b} \text { ) d) }}$ \\
\hline n-Hexane & $\mathrm{C}_{6} \mathrm{H}_{14}$ & 86.18 & $-95 \sim-100$ & 68.7 & 0.6603 & 17.90 & 50.80 & 0.290 & $2.5387 \times 10^{7}$ & {$[\mathrm{~A}]^{\mathrm{b}) \mathrm{d}(\mathrm{e})}$} & $0^{\text {b) d e) }}$ \\
\hline n-Octane & $\mathrm{C}_{8} \mathrm{H}_{18}$ & 114.23 & -56.8 & 125.7 & 0.7026 & 21.14 & 51.68 & 0.480 & $1.8634 \times 10^{6}$ & {$[\mathrm{~A}]^{\mathrm{cle})}$} & $0^{\text {c) e) }}$ \\
\hline n-Desane & $\mathrm{C}_{10} \mathrm{H}_{22}$ & 142.29 & -30 & 174.0 & 0.7300 & 23.24 & 52.30 & 0.835 & $1.7315 \times 10^{5}$ & {$[\mathrm{~B}]^{\mathrm{cec})}$} & $\sim 20 \min ^{(\mathrm{ce})}$ \\
\hline n-Dodecane & $\mathrm{C}_{12} \mathrm{H}_{26}$ & 170.34 & -9.6 & 214.5 & 0.7511 & 24.91 & 52.78 & 1.257 & $1.5351 \times 10^{4}$ & {$[\mathrm{~B}]^{\mathrm{c} \text { e) }}$} & $\sim 3$ days $\sim{ }^{c) e}$ \\
\hline n-Tetradecane & $\mathrm{C}_{14} \mathrm{H}_{30}$ & 198.39 & 5.5 & 252.5 & 0.7624 & 26.13 & 53.32 & 1.783 & $1.2645 \times 10^{3}$ & {$[\mathrm{~B}]^{\mathrm{cce})}$} & $\sim 3$ days $\sim \sim^{c) e}$ \\
\hline n-Hexadecane & $\mathrm{C}_{16} \mathrm{H}_{34}$ & 226.45 & 18.13 & $286 \sim 293$ & 0.7734 & 27.05 & 53.77 & 2.571 & $9.0072 \times 10^{1}$ & {$[\mathrm{~B}]^{\mathrm{c}(\mathrm{e})}$} & $\sim 3$ days $\sim \sim^{c) e}$ \\
\hline
\end{tabular}

a) $20^{\circ} \mathrm{C}$, b) $25^{\circ} \mathrm{C}$, c) $30^{\circ} \mathrm{C}$, d) Ultrasonication for $2 \mathrm{~min}$, e) $20^{\circ} \mathrm{C}$, Ultrasonication for $8 \mathrm{~min}$

Evolution pattern of oil droplets : $\quad[\mathrm{A}]$ $\sim 10^{\sim 2}$ (middle class) $\rightarrow \sim 10^{\sim 3}$ (visible class)

$[\mathrm{B}] \sim 10^{\sim 1}$ (fine class) $\rightarrow \sim 10^{\sim 2}$ (middle class)

$[\mathrm{C}] \sim 10^{\sim 1}$ (fine class) $\rightarrow \sim 10^{\sim 2}$ (middle class) $\rightarrow \sim 10^{\sim 3}$ (visible class)

滴では油滴が大きくなりすぎて分子拡散は期待 できない。数十 $\mathrm{nm}$ 径 (Sクラス) の油滴につ いては，超音波照射により一時的に形成された としても，極めて速い分子拡散あるいは合一 （小粒子 $(\mathrm{S}) \rightarrow$ 大粒子 $(\mathrm{M})$ ) )が起こるため，光 散乱測定では観測されなかった可能性もある。

タイプ（B）の油：炭化水素鎖長の長いへキサデカンの ような油は，粘度が大きいため超音波によって も破砕されにくいが，いったん微細化されてし まえば，蒸気圧が小さいために分子拡散を起こ しにくくなるので，成長は緩やかとなる。

タイプ (C) の油：タイプ (A） と同様に，粘度が低い ため水中に分散させるのは容易であるが，分子 拡散が起こりやすい（蒸気圧が大きい）ので分 散安定性に劣る。しかし, 疎水性分子の中でべ ンゼンのような極めて溶解性の高い油は，他の 油に比べて水中に溶解した分子が多数存在する ため，分子拡散は溶解状態で律速段階（小粒子 $(\mathrm{S}) \rightarrow$ 溶解 $\rightarrow$ 大粒子 $(\mathrm{M})$ ) をとるものと考えら れる。そのため, 溶解度の極めて小さなタイプ （A）のへキサンなどに比へ， Sクラスから M クラスへの成長が明確に観測されたものと考え られる。

また, 油の粘度は粒子径を決める重要なパラメーター

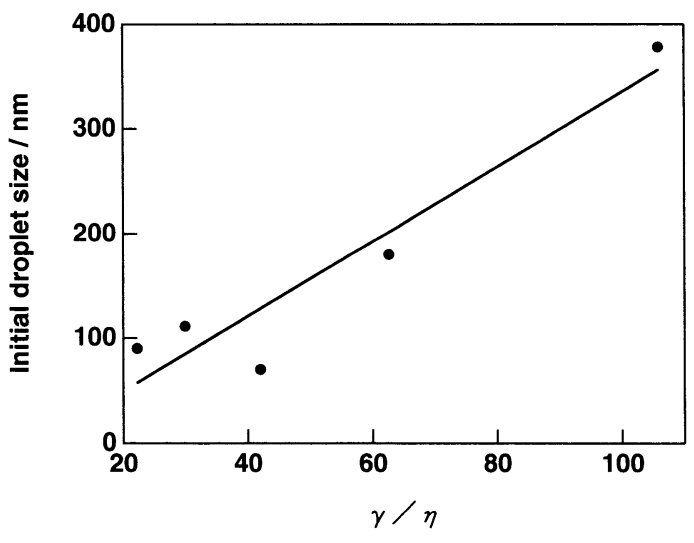

Fig.6 The initial size of the smallest droplet for alkane series, plotted against $\gamma / \eta$ of oils.

であることも分かった。調製初期段階の粒子径と $\gamma / \eta$ $(\gamma$ : 油と水の界面張力, $\eta$ : 油の粘度）の関係を Fig. 6 に示す。Fig. 6 から明らかなように，ほぼ界面張力が等 しい炭素数 8 から 16 の油の場合 (Table 2), 粘度の大 きい油ほど粒子径は小さくなっている。 $\gamma / \eta$ は, 界面活 性片が添加されている通常のエマルションを調製する 際, 機械的な分散・乳化処理を行った場合のサイズの限 界值を見積もる指標とされている ${ }^{199)}{ }^{20)}$ 。このことは，粒 子サイズは主として油の特性に支配されていることを支 持している。

ここで，油の物性だけではなく，水の物性にも注目す 


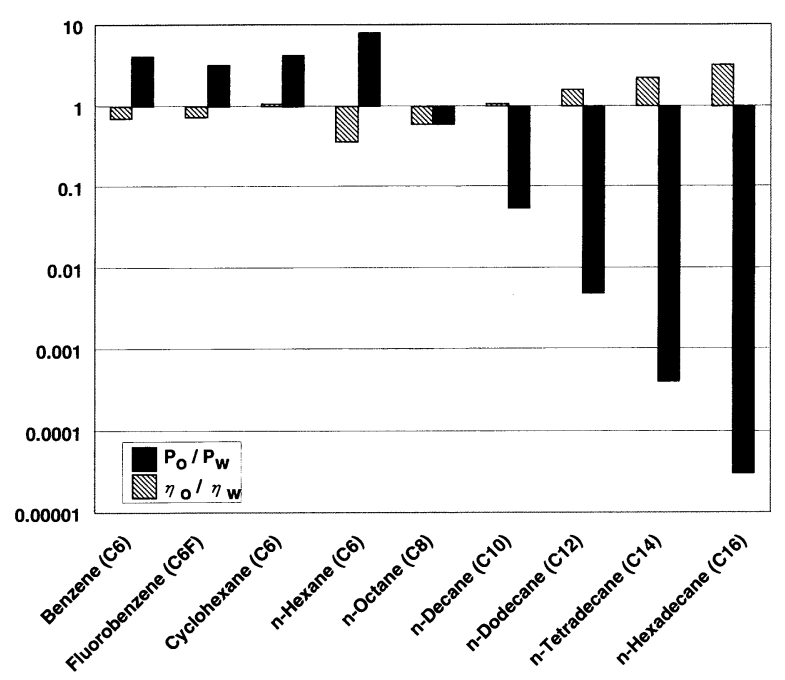

Fig.7 Ratio of viscosity and vapor pressure of the oils to those of water; $\gamma_{0} / \eta_{w}$ and $P_{o} / P_{w}$.

ると興味深い知見が得られる。種々の炭化水素類につい て，水と油の粘度や蒸気圧の比をとってみると，まず， 炭素数 8 のオクタンと炭素数 10 のデカンの粘度と蒸気 圧は，水の值にほほ等しい $\left(\mathrm{P}_{\mathrm{o}} / \mathrm{P}_{\mathrm{w}}, \eta_{\mathrm{o}} / \eta_{\mathrm{w}} \approx 1\right)$ ことに気 づく。また，その炭素数（8もしくは 10）の前後で大小 関係が逆転している（Fig. 7)。この境界点と成長過程の タイプに相関性があり, 水の物性が成長過程を支配して いる可能性を示唆している。特に，サーファクタントフ リーエマルションは, 油滴と水が直に接していることか ら水の影響をかなり受けていると考えて良いであろう。

また，温度を上昇させたり，電解質を添加することに より，コロイド溶液の分散安定性が低下することが知ら れている。デカン油滴の場合の $10^{\circ} \mathrm{C}, 50^{\circ} \mathrm{C}$ の粒子径分 布を Fig. 8 に示す ${ }^{14)}$ 。温度上昇における初期段階の S ク ラスやMクラスの油滴の共存はほとんど変わらないが, 四から明らかなように，低温 $\left(10^{\circ} \mathrm{C}\right)$ の場合に比べ，高 温 $\left(50^{\circ} \mathrm{C}\right)$ の場合は極めて短時間（数十分程度）で粒子 径が L クラスへと成長して，成長が促進されていること が分かる。初期段階の粒子径分布の粒子径（ピーク值） と温度の関係を Fig. 9 に示すと, 温度の上昇が S クラス から M クラスの成長に大きな影響を与えていることが 分かる。

また，電解質 $\mathrm{KCl}$ を $10 〜 100 \mathrm{mmol} / \mathrm{L}$ 添加すると， 初期の段階で 300-400 $\mathrm{nm}$ の M クラスの油滴が観測さ

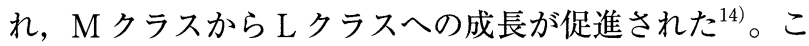
れは塩添加によって水分子間のネットワークの崩壊が引 き起こされ，疎水性水和を減少させるためである。また もう一つ重要な要因は, 電解質がサーファクタントフ リーエマルションの表面電荷を中性に変化させることが あげられる。ベンゼンやへキサデカンの油滴の場合, 解

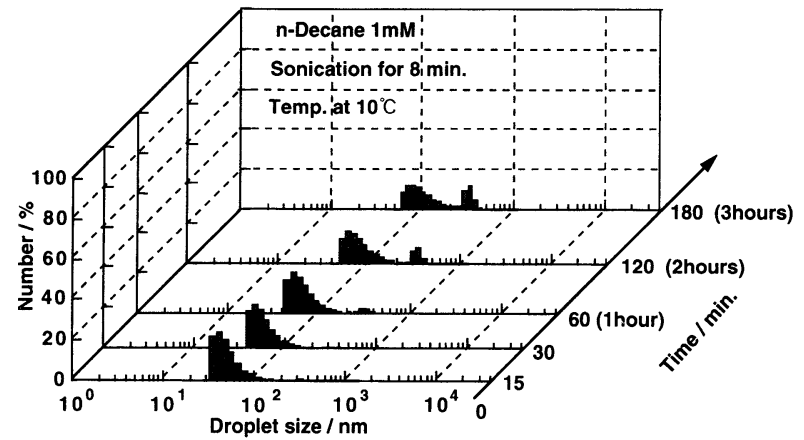

(a)

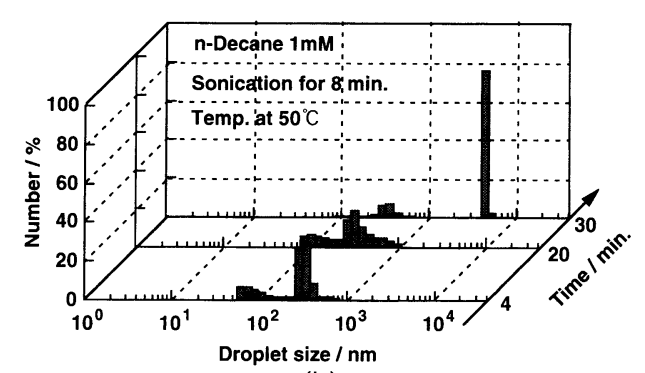

(b)

Fig.8 Size distribution of $\mathrm{n}$-decane droplets $(1 \mathrm{mM})$ at (a) $10^{\circ} \mathrm{C}$ and (b) $50^{\circ} \mathrm{C}$ as a function of time after sonication.

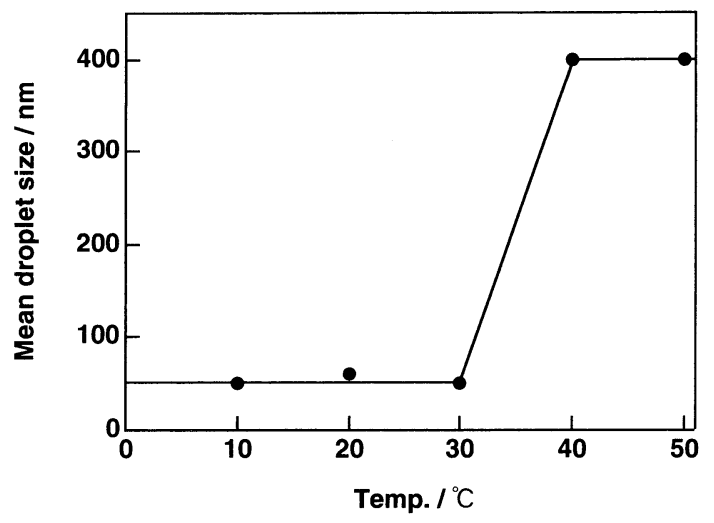

Fig.9 Temperature dependence of the initial size in $\mathrm{n}$-decane dispersion $(1 \mathrm{mM})$.

離基が存在しないにも関わらず負電荷を有することが観 測されている ${ }^{21)}$ 。の原因については以下のことが考え られる。(1)水中に存在しているヒドロキシイオン $\left(\mathrm{OH}^{-}\right)$もしくは，超音波照射によって生成されたヒド ロキシイオン $\left(\mathrm{OH}^{-}\right)$が油相と水との間の誘電率の差に より油滴表面により多く吸着する22), 23)，(2)水和水の配列 に伴う永久双極子と誘起双極子の秩序化による影響など が考えられる。

\section{4. ベンゼン油滴の 3 段階成長のフリーズフラクチャー TEM（FFEM）による直接観察}

これまで述べてきたように，油の種類により油滴の段階 


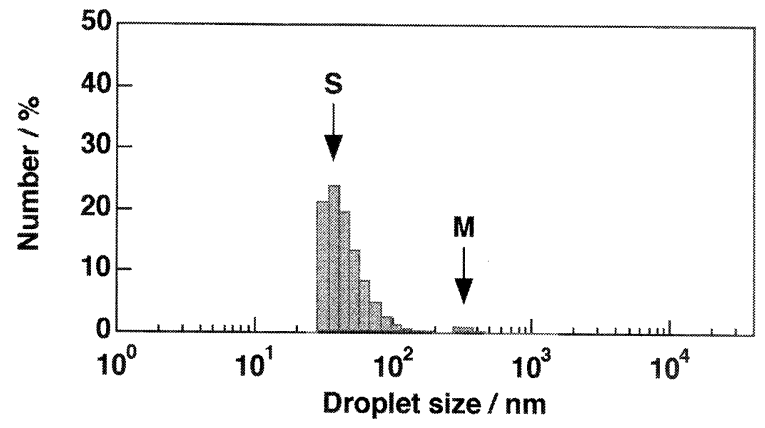

(a)

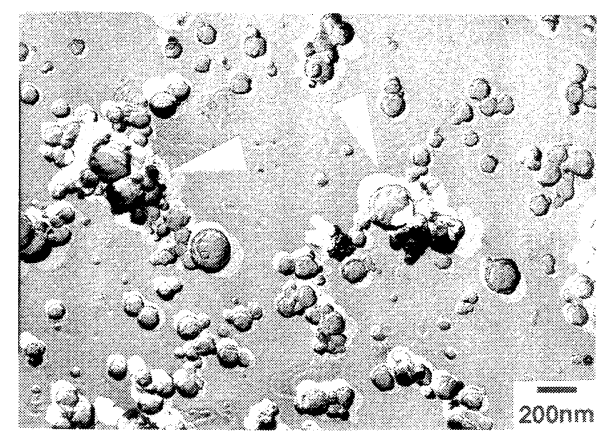

(b)

Fig.10 (a) Size distribution measured by dynamic light scattering (Sub-micron particle analyzer system 4700 : Malvern Instrument Co.), and (b) FFEM image of benzene droplets dispersed in water $(30 \mathrm{mM})$ immediately after sonication.

成長（タイプ(A) (B) (C)）が異なることが分かった。そ のなかで, 特にベンゼン油滴は典型的な 3 段階成長が観 察された。そこで, ベンゼン油滴をフリーズフラク チャーTEM（FFEM）を用いて，直接観察することを 試みた。フリーズフラクチャーレプリカ法は，液体試料を 液体プロパンや液体窒素中に投入して，1000 $10000^{\circ} \mathrm{C} / \mathrm{s}$ の凍結速度で試料を急速に凍結して溶媒である水分子を アモルファス状態で固定化することができる。ベンゼン 油滴のような調製後約 30 分という短い時間で $\mathrm{S}$ クラス, $\mathrm{M}$ クラス, L クラスヘと刻々と変化するような試料から なる分散液内部の状態をより正確に捉えるためには，瞬 間凍結によって固定化できるフリーズフラクチャー法は 極めて有効である。さらに，階層構造（S クラス， M ク ラス，Lクラス）などを視覚的に捉えることができる魅 力をも持っている。

まず，調製直後の動的光散乱法（DLS）による粒子径 分布（数分布）と FFEM 像を Fig. 10 に示す ${ }^{24)}$ 。Fig. 10 （a）に示すように，20〜100 nm（S class）の主な粒子径 分布と 300 500 nm（M クラス）の小さな粒子径分布が 観察された。FFEM 像（Fig. 10(b)）を見ると，30〜200 nm

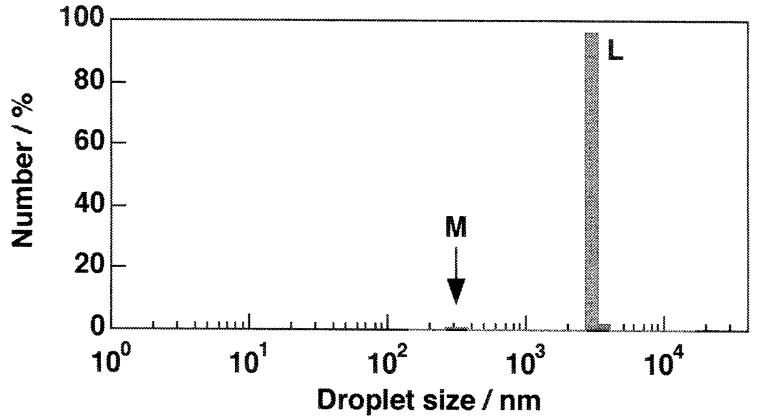

(a)

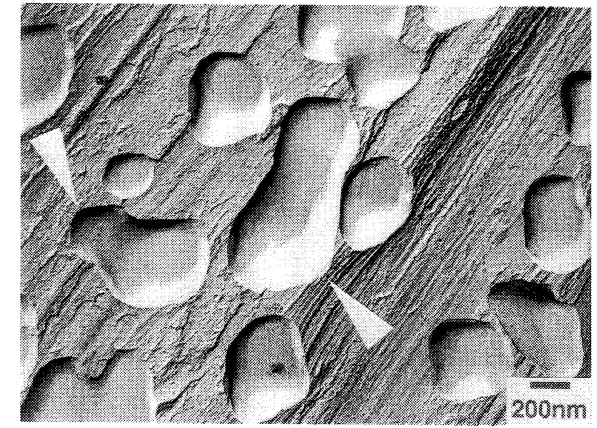

(b)

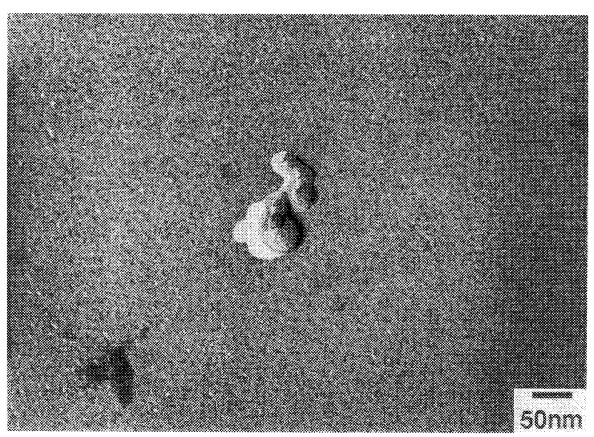

(c)

Fig.11 (a) Size distribution measured by dynamic light scattering (Sub-micron particle analyzer system 4700 : Malvern Instrument Co.), (b) FFEM image of benzene droplets dispersed in water, and (c) another FFEM image of benzene droplets $(30 \mathrm{mM}) 60 \mathrm{~min}$ after sonication.

の油滴が観察されている。そのなかでも特に，30〜100 nm の油滴（DLS でのSクラスの粒子径分布に相当）が多数 観察された。また，200～500 nm の凝集体（白矢印）を 数個観察することができた。これらのサイズもまた， DLS で得られた M クラスの粒子径分布とよく一致して いる。これらの FFEM 結果は，DLSによって観測され た離散的な粒子径分布を支持していることが分かった。

次に, 調製後 60 分後における DLS から得られた粒子 径分布（数分布）と FFEM 像を Fig. 11 に示す。Fig. 11 （a）に示すように，DLS では S クラスの粒子径分布は 
観測されず，200〜 400 nm（M クラス）の小さな分布と $3000 〜 4000 \mathrm{~nm}$ (L クラス）の大きな分布を観測するこ とができた。Fig. 11(b) の FFEM 像によって M クラス に相当する 200〜 $500 \mathrm{~nm}$ の油滴が観察された。また, Fig. 11 (c) に示すように, 60 分後においても, DLS で は捉えることができなかった S クラスの小さな凝集体を 観察することができた。さらに，我々は，Fig. 11(b) に 示すように，隣接する M クラスの 2 つの油滴が合一し ている FFEM 像（白矢印）を得ることができた。一方， Fig. 11 (c) に示すように，小さな油滴はお互いに凝集し ていることが分かった。我々は先に，ベンゼンに代表さ れる 3 段階成長が等比級数的にサイズを成長させていた ことから，この成長過程はすべて同様の凝集過程として 考えてきたが, FFEMの結果から，サイズの小さな $\mathrm{S}$ クラスの油滴は “凝集” して成長するが, サイズが大き な M クラスの油滴は，“合一”して成長しており，Fig. 12 に示すような成長モデルを示すことができる ${ }^{24)}$ 。

この成長過程（Sクラスの油滴は “凝集”， M クラス の油滴は “合一”）の違いをDLVO 理論を用いて考えて

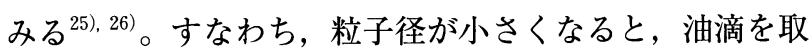
り囲んでいる電気二重層がオーバーラップするため, 強 い静電気的斥力を生み出す $\left.{ }^{27)}, 28\right)$ ので，S クラスの油滴は 接近した際に互いに静電的斥力を受け，個々の油滴の形 や特徽を維持したまま凝集する（ただし，合一はしな い)。一方，M クラスの油滴の場合，接触率から考えて

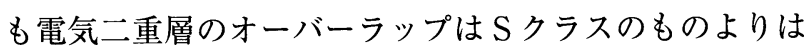
少なく, M クラスの油滴間の静電気的反発は弱くなるの で，隣接する M クラスの油滴はお互いに合一したと考 えている。

また，FFEMによる直接観察において，如何に小さ な油滴が存在しているかを確認することは, 大恋興味深
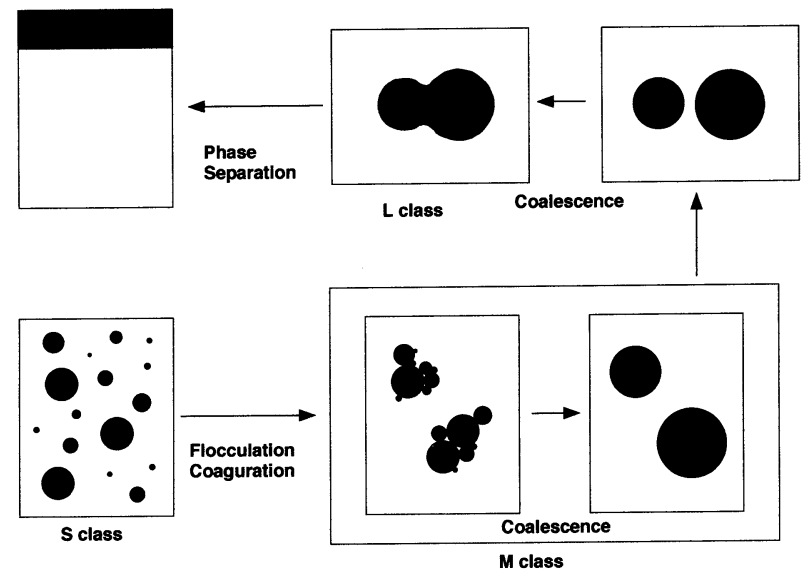

Fig.12 Schematic illustration of different steps in droplet growth from $\mathrm{S}$ to $\mathrm{M}$ and $\mathrm{M}$ to $\mathrm{L}$ class droplets obtained by FFEM.

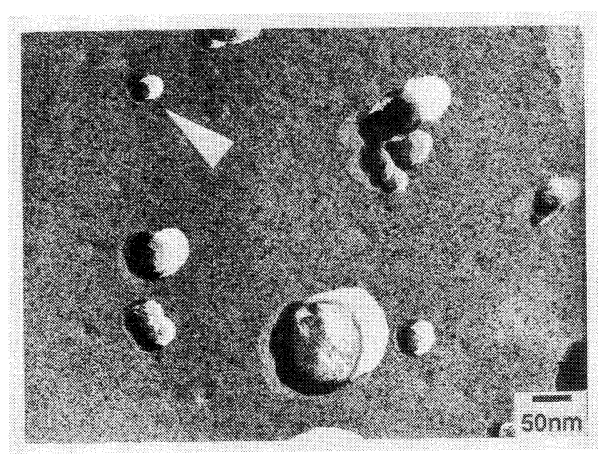

Fig.13 High-resolution FFEM image of benzene droplets (30mM).

いところである。一般に，機械的な乳化手段を用いた場 合には，形成されるエマルション滴のサイズには限界が あり，直径 $50 \mathrm{~nm}$ 以下の滴を調製することは困難とされ ている ${ }^{1), 20)}$ 。しかし, 今回, ベンゼンを用いた場合にお いては, 平衡系のエマルションであるマイクロエマル ションのサイズに相当する直径 $20 \mathrm{~nm}$ 前後の微細な油滴 (白矢印) も観測することができた $\left(\right.$ Fig. 13) ${ }^{24)}$ 。つま り,このサイズ（直径 $20 \mathrm{~nm}$ 前後）の油滴は, 油の機械 的破砕によって形成されたのではなく，水中に分子状で 溶解していた油分子が析出して形成（核形成）した可能性 があることを意味している。このことは次式の OstwaldFreuindlich の式 ${ }^{3)}$,29) からも支持される。この式は飽和状 態から液滴などの新しい相が生ずる際の濃度と粒子径の 関係を示している。

$\mathrm{S}(\mathrm{r}) / \mathrm{Se}=\exp \left(2 \gamma \mathrm{V}_{\mathrm{m}} / \mathrm{rRT}\right)$

$\mathrm{S}(\mathrm{r})$ と Se は，それぞれ超音波によって調製した油滴 の出現濃度と平衡時の濃度である。 $\gamma$ は界面張力, $\mathrm{V}_{\mathrm{m}}$ は 油のモル体積, $\mathrm{R}$ は気体定数, $\mathrm{T}$ は絶対温度, $\mathrm{r}$ は油滴 の半径である。

ベンゼンの場合, 示差屈折率, 密度と濃度の関係 （Fig. 14）から明らかなように，超音波照射を行うと， $25^{\circ} \mathrm{C}$ における溶解度（ $\mathrm{Se}=23 \mathrm{mM}$ ) よりも 1.3 倍高い濃 度 $(\mathrm{Sr} \approx 30 \mathrm{mM})$ から油滴が形成することが分かった ${ }^{15)}$ 。 それぞれの值を式（2）に代入すると，半径 $\mathrm{r}=10 \mathrm{~nm}$ を得 ることができる。このサイズ, 直径 $2 \mathrm{r}=20 \mathrm{~nm}$ は $\mathrm{DLS}^{15)}$ と $\mathrm{FFEM}^{24)}$ によって得られた粒子径分布と一致している。 つまり，このことは S クラスのうち特に $50 \mathrm{~nm}$ 以下の油 滴は, 水への油分子の溶解（過飽和）から核形成して生 み出されることが示唆される。また, ベンゼンの場合, 超音波処理時間の延長や処理温度の上昇により, Sクラ スの油滴数を増大させることができることなどからも裏 付けられる。溶解度の小さなへキサンやシクロヘキサン の場合では，微細油滴が観察されないこと ${ }^{15)}$ からも，溶 解度の関与が示唆される。また, ベンゼンの M クラス 


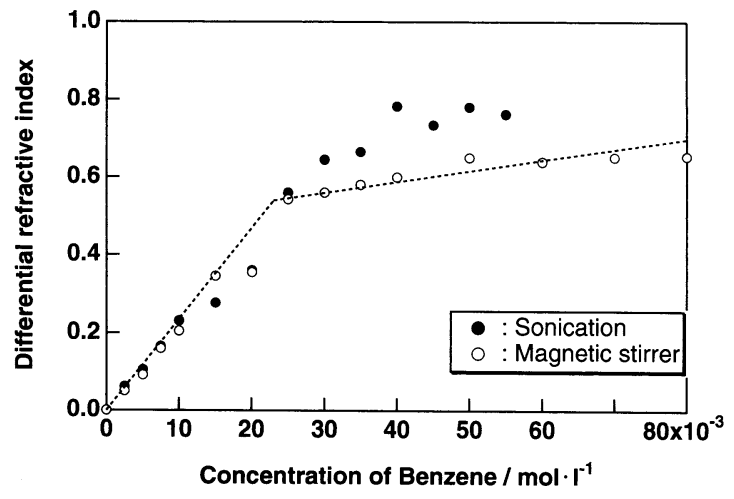

(a)

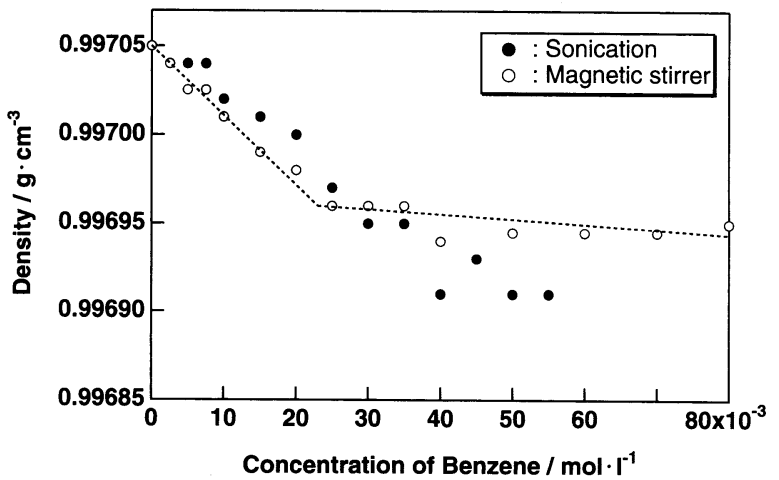

Fig.14 Relations between (a) differential refractive index; (b) density and concentration of Benzene at $25^{\circ} \mathrm{C}$. Ultrasonic treatment $(2 \mathrm{~min})(\mathbf{O})$ and magnetic stirrer treatment $(\bigcirc)$.

の油滴は Fig. 6 の直線関係に従う $(\gamma / \eta=35.0 / 0.564 \approx 62$, droplet size $(\mathrm{M}$ class $) \approx 300 \mathrm{~nm})$ が, Sクラスの油滴は 従わない。これらの結果を合わせると, 超音波照射によ る破砕によって形成された油滴は $\mathrm{M}$ クラスまでであり, $\mathrm{S}$ クラス（特に $50 \mathrm{~nm}$ 以下の大きさ）の油滴は, 溶解 （過飽和）していた油分子の核形成という段階を経て形 成されているものと考えられる

\section{5. 油滴としての分散安定性に優れた油の探索}

前述したように，炭素数 6 のへキサンのような短鎖の アルカンよりも炭素数 16 のへキサデカンのような長鎖 のアルカン，また，スクアランのような長鎖かつ分岐構 造を有する油の方が分散安定性が極めて優れていること が分かってきた。そこで, 疎水基鎖長が長く, かつ分枝 構造を有し，カルボキシル基という弱い極性部位を持つ 脂肪酸や脂肪酸エステルなどの油脂類を用いてサーファ クタントフリーエマルションの調製を試みた ${ }^{30)} 。$

まず，油脂である脂肪酸エステルの共通骨格であるオ レイン酸について検討してみた。水中に分散させたオレ イン酸滴の粒度分布を Fig. 15 に示す。なお, 分散はボ

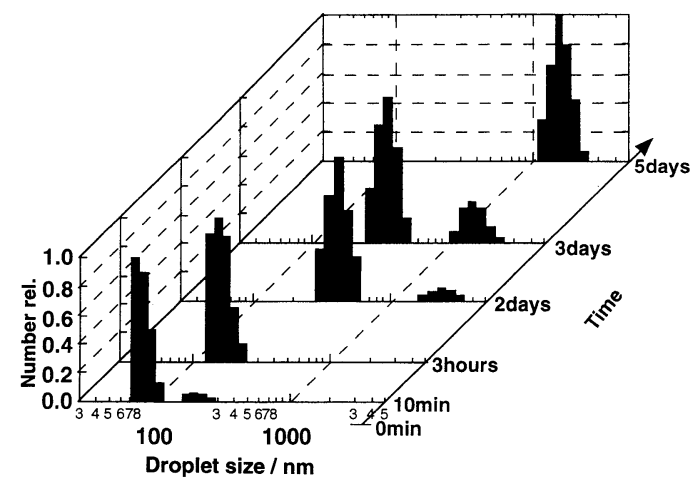

Fig.15 Size distributions at various elapsed times of oleic acid droplets in water at $30^{\circ} \mathrm{C}$ measured by a dynamic light scattering method.

ルテックシミキサーで 1 分間擋拌した後，超音波発振器 （ブラウンソニック 220 型 $125 \mathrm{~W}$ ）で 8 分間, 超音波を 照射することにより行った。Fig. 15 から明らかなよう に, 油滴調製 10 分後では, 数十 $\mathrm{nm}$ にピークを持つ $\mathrm{S}$ クラスと数百 $\mathrm{nm}$ にピークを持つ $\mathrm{M}$ クラスの粒度分布 が観察され，時間の経過とともに離散的（不連続）に成 長した (ベンゼン滴など ${ }^{15)}$ と同様)。一方，アルコール 部分のアルキル鎖長が短い脂肪酸エステルのメチルオ レート滴の場合（Fig. 16），調製直後では数十 nmに ピークを持つ S クラスだけのピークが観察され，その $\mathrm{M}$ クラスへのシフトは連続的に起こった。この傾向は, アルキル鎖長をより長くしたデシルオレートとオレイル オレートの場合にも観察され，また L クラスの粒子は数 分布で表現すると無視できるほど少なかった。さらに， メチルオレートの場合，その粒子径が 2 倍成長する のに $2 \sim 3$ 日間要したが，デシルオレートやオレイルオ レートの場合は $2 \sim 4$ 週間要し, 粒子径の成長時間はエ ステル鎖長の増加に伴い鈍くなる傾向にあった。次に, 用いた脂肪酸エステルの中で大きな分枝構造を持ってい るグリセロールトリオレート滴の粒度分布を Fig. 17 に

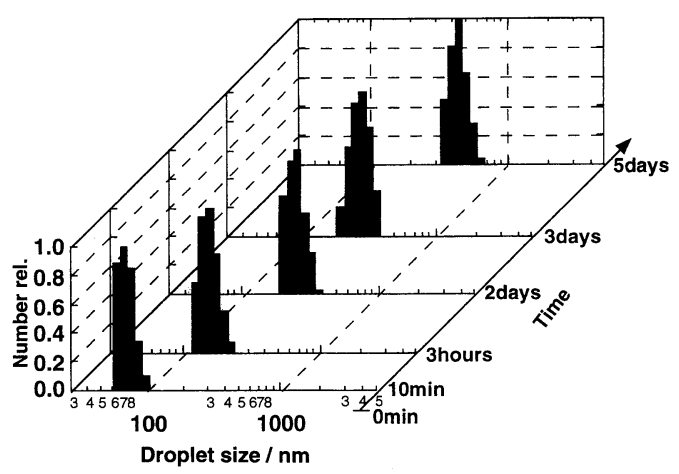

Fig.16 Size distributions at various elapsed times of methyl oleate droplets in water at $30^{\circ} \mathrm{C}$ measured by a dynamic light scattering method. 


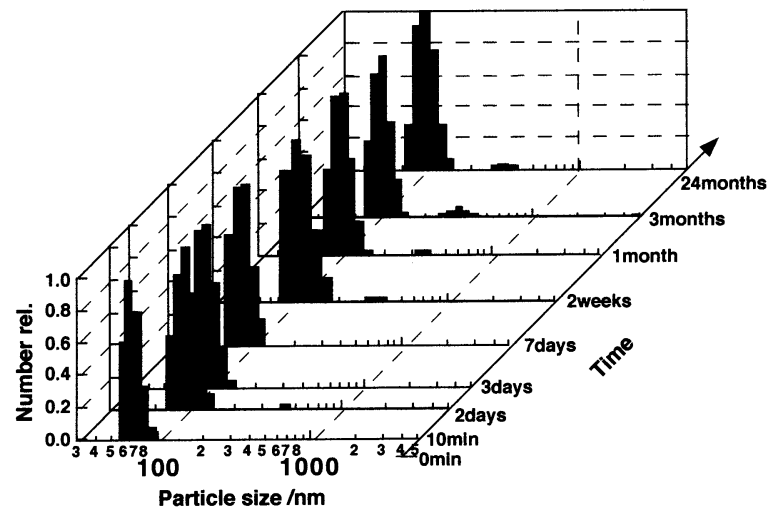

Fig.17 Size distributions at various elapsed times of glycerol trioleate droplets in water at $30^{\circ} \mathrm{C}$ measured by a dynamic light scattering method.

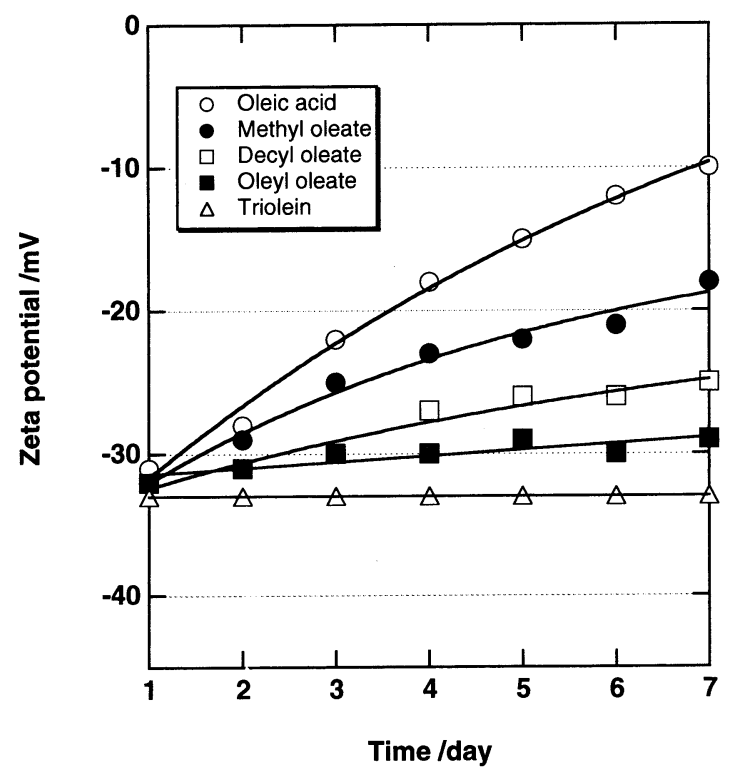

Fig.18 Changes in zeta potential of oil droplets dispersed in water as a function of time. Oleic acid ( $\mathrm{O})$, methyl oleate $(\mathbf{)})$, decyl oleate $(\square)$, oleyl oleate $(\square)$, and glycerol trioleate $(\triangle)$.

示す。ここで注目すべきことは，調製 10 分後に観察さ れた Sクラス（数十 $\mathrm{nm}$ ）の粒子径が，24 ケ月間保持さ れていることである。ちなみに，この粒子径は現在もな 抒持続している。表面電荷（ら電位）も粒子径の変化に 対応して経時変化を示し（Fig. 18），油滴を調製した直 後の場合，油滴の表面は油の種類に依存せずに約マイナ ス $32 \mathrm{mV}$ の $\zeta$ 電位を持っていたが，分散安定性の悪い 油であるオレイン酸は時間とともにその絶対值を減少さ せた。これは, 粒子径の増大に伴う油滴表面の水和層の 減少によるものであり，以下に述べる FT-IR の結果か らも裏付けられる。安定性の異なる 3 種類の油滴分散液 の FT-IR スペクトル測定を行い，カルボキシル基のサ イトから検討した。その結果，グリセロールトリオレー
卜の場合，水が共存しない時のカルボキシル基のピーク は $1741 \mathrm{~cm}^{-1}$ であったが，油滴を調製した直後に高波数 側へシフトして 7 日間にわたって変化しなかった。一 方，オレイン酸やメチルオレートの場合，調製した直後 は上記と同様に高波数側へシフトしたが，時間の経過に 伴い徐々に水が共存しない油単独のピークに近づいて いった。一般に，オレイン酸の $\mathrm{C}=\mathrm{O}$ 伸縮振動はダイ マー状態の場合 $1708 \mathrm{~cm}^{-1}$ の吸収を示すが，モノマー状 態の場合 $1760 \mathrm{~cm}^{-1}$ と高波数側に観測されること到を考 え合わせると, 吸収ピークの高波数側へのシフトは, 油 滴の調製に伴い隣接する油分子のカルボニル基同士の相 互作用が弱まって分子内の $\mathrm{C}=\mathrm{O}$ 間の結合定数が増加し たためと考えられる。つまり, 脂肪酸エステルの場合, 水中における油滴の調製に際して油滴の表面には純粋な 油だけの構造とは異なる構造が形成されるものと考えら れる。また，不安定なオレイン酸やメチルオレート油滴 で観察されたピーク位置が経時変化によって復帰したの は, 油滴の合一や成長に伴い油滴の表面層が減少して純 粋な油同士の分子配列を再形成するために起こったもの と考えられる。

ここで用いた脂肪酸エステルの界面張力および密度 は, 種類によって大きな違いはないが, 粘度はアルコー ル部分のアルキル鎖長などの増加に伴い，メチルオレー ト $(4.88 \mathrm{mPa} \mathrm{s})$, デシルオレート $(12.7 \mathrm{mPa} \mathrm{s})$, オレイ ルオレート $(24.0 \mathrm{mPa} \mathrm{s})$, グリセロールトリオレート （56.0 mPa s）と増加する。つまり，アルキル鎖長の長い 油, また分枝構造を有する油ほど粘度は大きくなり, 分 散安定性に優れた油滴を調製できるものと考えられる。 ところが，油の種類によっては，油滴の分散安定性が油 の粘度と比例関係にないものも存在した。例えば，前述 したように，脂肪酸エステルと共通の骨格を持つオレイ ン酸は高粘度を有している（23.0 m Pas）にも関わらず, 油滴の分散安定性は悪かった。そこで, これらの分散油 滴の成長過程を比較してみることにする。エマルション が物理化学的に破壞分離していく過程の違いについてに は，前述したように，粒子同士が㠜集・合一を起こす現 象と, 分子拡散による成長の 2 つが考えられる。後者 は，オストワルド熟成と呼ばれ，物質が微小になるほど 溶解度が増大するという事実に起因する現象であり，小 さい粒子を形成している物質が分散媒中に溶解し，拡散 によって大きい粒子に吸収あるいは吸着され，粒度分布

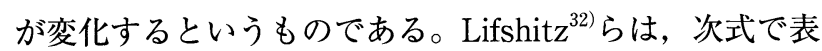
される微粒子のオストワルド熟成の理論 (LSW 理論) を提唱した。また, Taylor ${ }^{33) や ~} \mathrm{Kabalnov}^{34)}$ はこの式を用 いて，液滴のオストワルド熟成を証明している。

$\omega=\mathrm{dr}^{3} / \mathrm{dt}=8 / 9 \cdot \mathrm{DC}_{\infty} \mathrm{M} / \mathrm{\rho}^{2} \mathrm{RT}$ 


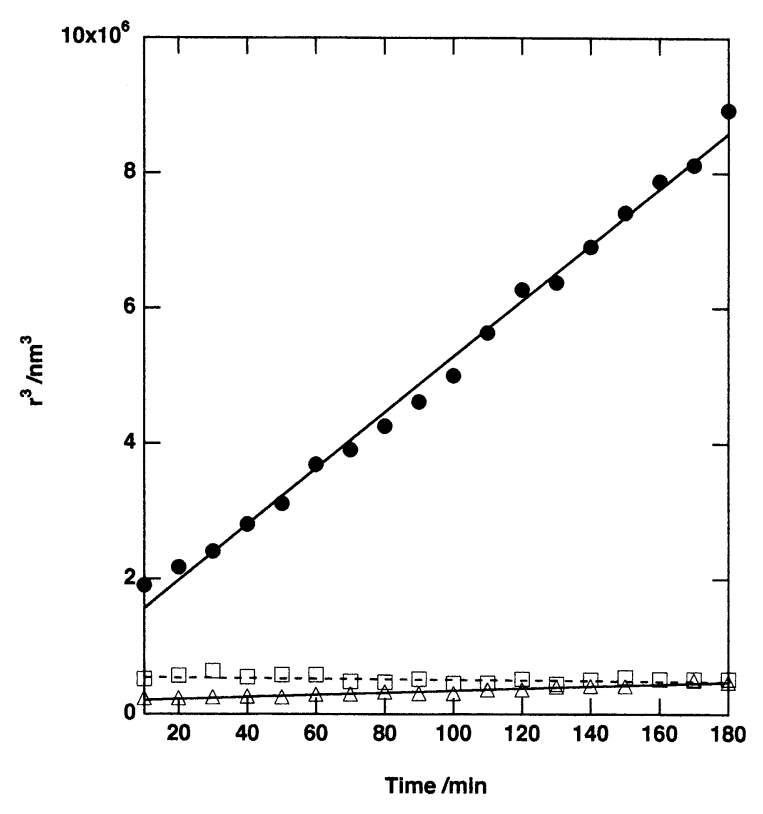

Fig.19 Plots of the cube of droplet size as a function of time. Oleic acid $(\mathbf{O})$, methyl oleate $(\triangle)$, and glycerol trioleate $(\square)$.
ここで, D は分散媒中に溶解した分散相の拡散係数, $\mathrm{C}_{\infty}$ は分散相の水に対する溶解度, $\gamma$ は油 $/$ 水 2 相間の界面 張力, $M$ と $\rho$ はそれぞれ分散相の分子量と密度, $r$ は系 の平均粒子半径である。

分散安定性の悪いオレイン酸およびメチルオレート, 分散安定性が最も良いグリセロールトリオレート滴の $\mathrm{r}^{3}$ 值の経時変化をプロットした（Fig. 19）。なお，測定時 間はオレイン酸, メチルオレート油滴の M クラスへの 成長が観察された 3 時間である。オレイン酸油滴の $\mathrm{r}^{3}$ の值は時間の経過に伴い, 著しい比例関係を示した。一 方, 油滴の安定性が悪いメチルオレートの場合も $\mathrm{r}^{3}$ の 若干の増加が認められたが, メチルオレートの $\omega$ 值はオ レイン酸の $\omega$ 值の 40 分の 1 であった。したがって, オ レイン酸の場合のオストワルド熟成の成長速度はメチル オレートの場合と必ずしも同じではない。一方，グリセ ロールトリオレートの $\mathrm{r}^{3}$ 值はほとんど経時変化を示さ なかった。この測定時間（10 分から 180 分）における オレイン酸滴の粒子径の体積分布と数分布の挙動を Fig. 20 (a) および（b）に示す。体積分布で表現すると大き な粒子に属する分子の割合の変化が分かり，また数分布

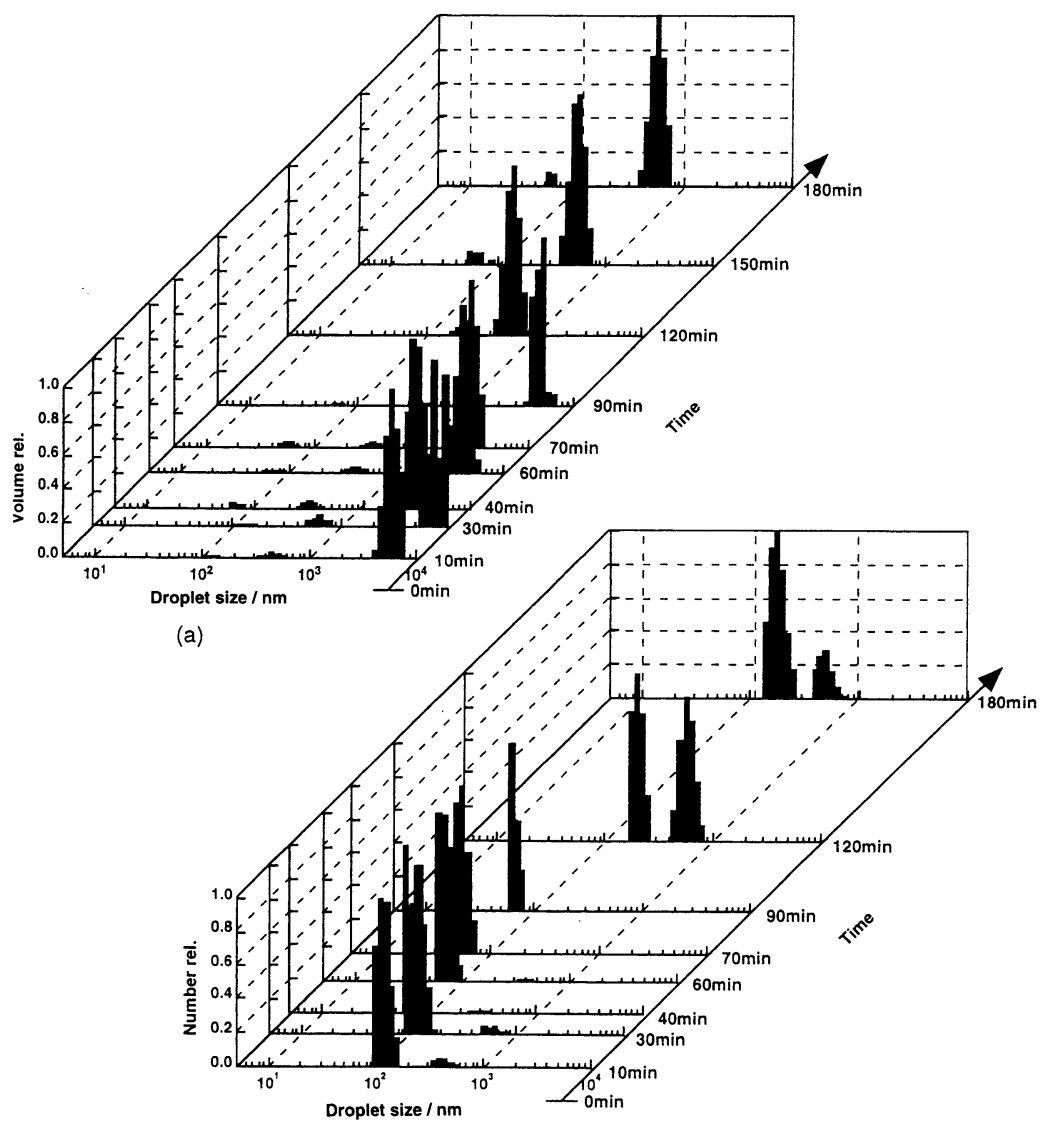

(b)

Fig.20 Size distributions; (a) volume and (b)number distribution, at various elapsed times of oleic acid droplets in water at $30^{\circ} \mathrm{C}$ measured by a dynamic light scattering method. 


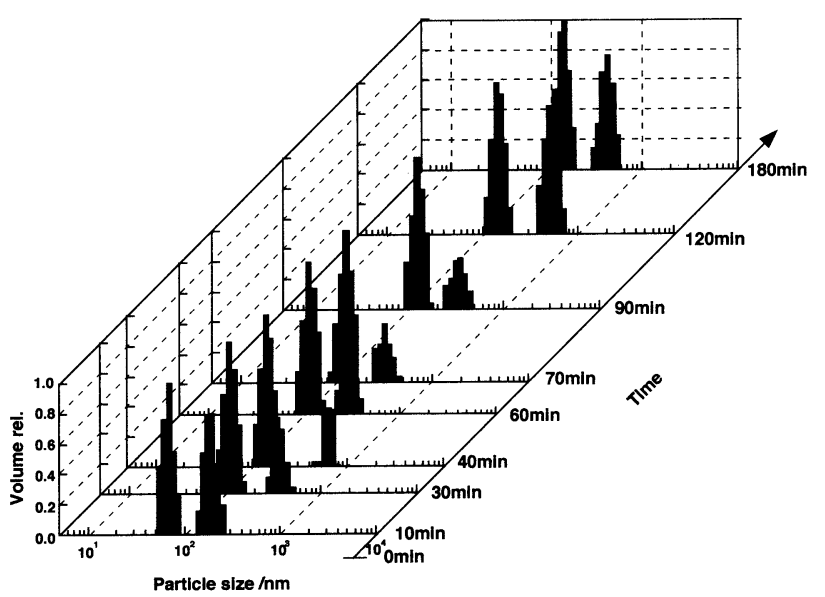

Fig.21 Size distributions (volume distribution) at various elapsed times of methyl oleate droplets in water at $30^{\circ} \mathrm{C}$ measured by a dynamic light scattering method.

で表現すると小さな粒子の位置がより正確にわかるの で，Fig. 20(a) からはS クラスの微小粒子が時間経過に 伴い小さくなっていく傾向，さらに（b）からは Lクラ スの大粒子が 90 分以降観測されなくなる傾向が分かる。 これは，オストワルド熟成による成長プロセスを支持す るものである。つまり，小さい粒子の分子拡散により大 きい粒子の成長が起こり，クリーミングしたことが考え られる。一方，Fig. 21 に示すメチルオレート油滴の場 合，オレイン酸の場合とは異なり，その体積分布からも 小粒子の連続成長が確認される。すなわち, メチルオ レートをはじめとする脂肪酸エステルの場合の微小油滴 の成長は凝集·合一によるものであると考えられる。

\section{6. 別の油の共存による油滴の安定性の向上}

また我々は，分散安定性が悪いベンゼンやテトラリン 滴に，それ自身で分散安定性が極めて良い $\mathrm{n}$-ヘキサデ カンあるいはスクワランを少量添加すると，分散安定性 が向上することを見出した ${ }^{17)}$ 。テトラリンにへキサデカ ンを添加した場合の平均粒子径の経時変化を Fig. 22 に 示す。図から明らかなように，テトラリンのみの分散油 滴は数十分程度で成長するが，へキサデカンを添加する と粒子径はほとんど変化しなくなった。油/水界面張力 を測定したところ，テトラリン中のへキサデカンの濃度 が増加していくに従って増加することが分かった（Fig. 23）。このことは, 疎水性の高いへキサデカンが油/水界 面に配向していることを示し，あたかも界面活性剤のよ うに作用していることが分かった。また，ベンゼンにへ キサデカンを少量添加した場合の目視による経時変化の 観察結果を Fig. 24 に示す。写真から明らかなように, ヘキサデカンを少量添加すると安定性が飛躍的に向上し ている。そこで，グリセロールトリオレートにも同様な

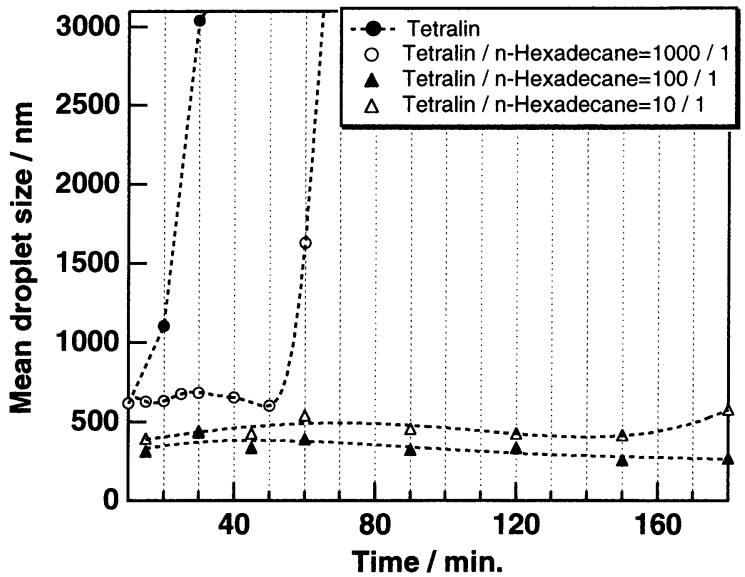

Fig.22 Temporal change of droplet size in tetralin dispersion as a function of time on $\mathrm{n}$-hexadecane addition. Mixing ratio to $1 \mathrm{mM}$ tetralin is $1: 1000(\bigcirc), 1: 100(\mathbf{A})$, and $1: 10(\triangle)$. Tetralin alone $(\mathbf{O})$.

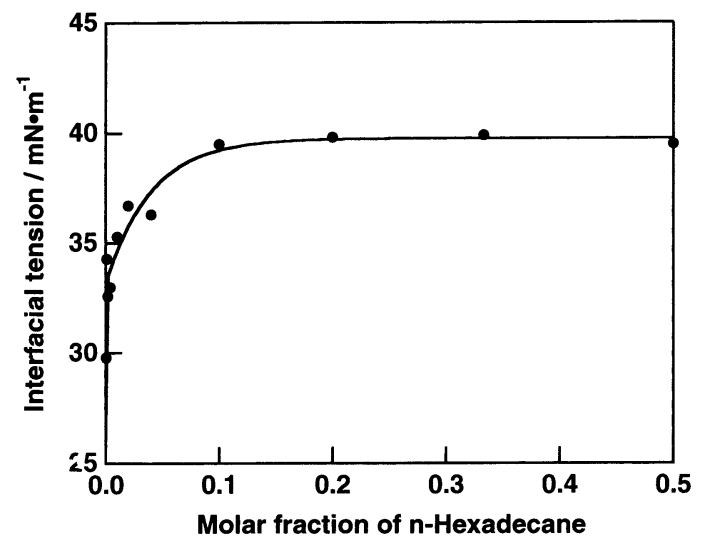

Fig.23 Interfacial tension $(\gamma)$ for tetralin-water boundary at various contents of $n$-hexadecane $\left(30^{\circ} \mathrm{C}\right)$.

作用があるのか確かめてみた ${ }^{30)}$ 。Fig. 25 に示すように， 少量のグリセロールトリオレートを添加することでオレ イン酸の $\omega$ 值の経時変化に対する傾きは極端に小さく なった。この場合も，n-ヘキサデカンの場合と同様に， オレイン酸滴の表面近傍にグリセロールトリオレートが 局在化し，油滴を安定化させているものと考えられる。

これまで述べてきたように，油単独，混合油のいずれ の場合においても，長鎖かつ分岐を有する分子を用いた 場合の方が水中における油滴の分散安定性は向上してい る。これは, 疎水性/親水性のバランスから考えた場合 には異常な現象に思われるが，実際には油/水界面に配 向するとは考えにくい疎水性の高い油分子が油滴表面近 傍に局在化することにより粒子が安定化されていること を意味する。それでは, なぜ, 疎水性の高い長鎖かつ分 岐が多い油分子が油/水界面に配向するのであろうか。 これまで，分散安定性の機構を検討してきた中で，長鎖 


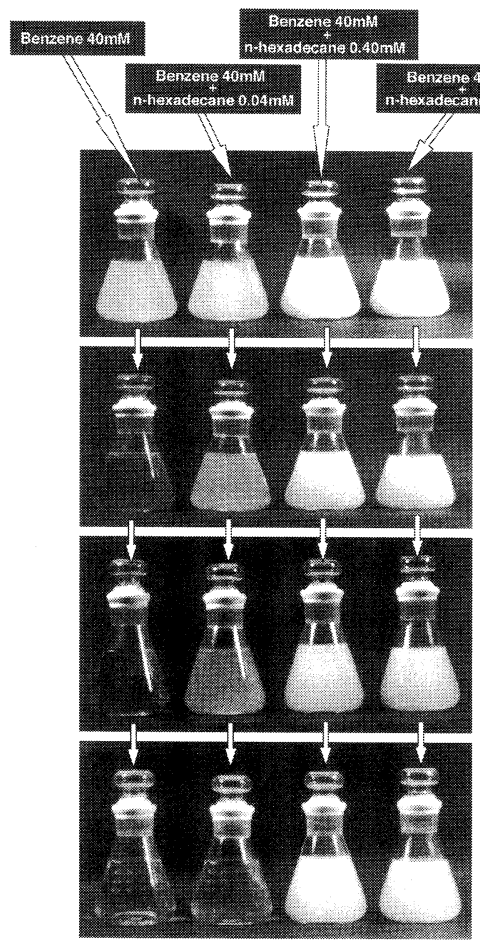

RIGHT

AFTER SONICATION

(Sonication time; $8 \mathrm{~min}^{\text {. }}$ )

AFTER 5 HOURS

AFTER 1 DAY

AFTER 1 MONTH

Fig.24 Photographic recording of droplet stabilization for $\mathrm{n}$-hexadecane/benzene mixture in water at $30^{\circ} \mathrm{C}$.

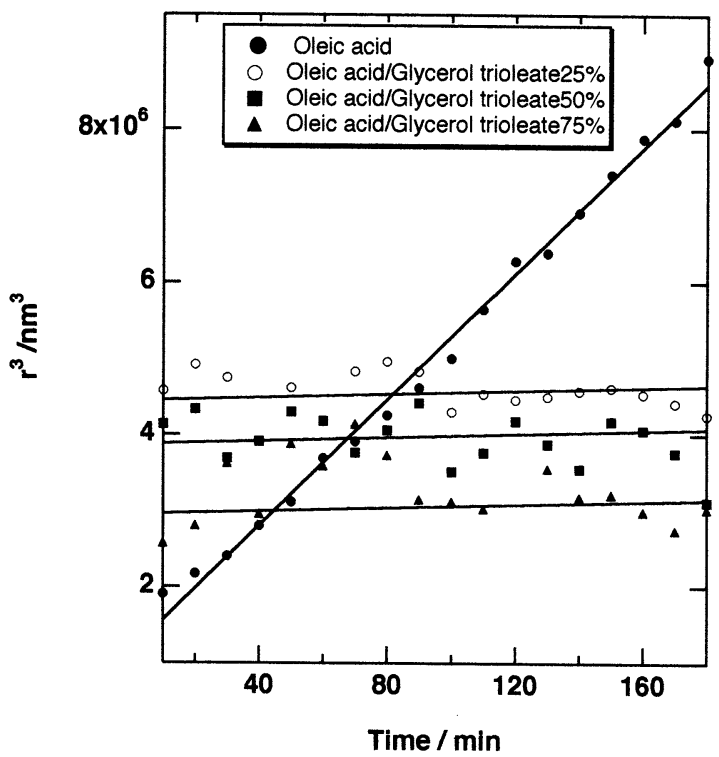

Fig.25 Plots of the cube of droplet size at various contents of glycerol trioleate as a function of time at $30^{\circ} \mathrm{C}$. Oleic acid/glycerol trioleate $=25 \%(\bigcirc), 50 \%(\boldsymbol{\square}), 75 \%(\mathbf{\Delta})$, and $100 \%$

炭化水素類のもつ大きな粘度と分散安定性の相関性を見 出し, 粘度の大きな油がより強固な界面を形成して分散 安定性を向上させる（凝集・合一を妨げるなどの効果が ある）ものと考察してきた。また，もう一つの理由とし て, 分子の構造と分子の吸収エネルギーの寄与が考えら れる。例えば, 油分子自身の $\mathrm{C}-\mathrm{C}, \mathrm{C}-\mathrm{H}$ 伸縮振動など
によるエネルギーの吸収が, 界面自由エネルギーを吸収 して低下させているという考えである。炭化水素鎖長の 長い油分子の方が鎖長の短い油分子より吸収されるエネ ルギーは大きいはずであり, 実験結果でもへキサデカン のような長鎖アルカンは分散安定性に優れていた。ちな みに，シリコン油を用いると安定性の高いエマルション を調製できるのも $\mathrm{Si}-\mathrm{O}$ の吸収が大きいためと考えられ る。また，エントロピー的に考察しても炭化水素鎖長が 長い方がエントロピーは増大するので, 結果としてエネ ルギーは減少する。ベンゼンのように構造を変化させる ことのできない油より，炭化水素鎖長の長いへキサデカ ンのように水中もしくは油中である程度自由に変形でき る（例えば，直線状，糸まり状など）方がエントロピー は大きくなる。また，オレイン酸は二量体を形成するの で，エントロピーが減少して分散安定性が低下すると考 えられる。これらの分子レベルでの因子がうまく組み合 わされたとき, 分散安定性のより良いエマルションが調 製できるものと考えられる。つまり，液/液分散系にお ける液体微粒子の粒子径や分散安定性をコントロールす るためには，マクロな概念（例えば，界面張力，粘度な どの物性值）だけで検討するのではなく，分子レベルで の検討が必要であろう。

\section{7. おわりに}

詳細は先の総説 ${ }^{12-14)}$ に誰る部分もあるが，現時点まで に得られた結果を整理すると以下のようになる。

1. 界面活性剂が存在しない多量の水々少量の油だけか らなる系に，超音波などを用いて強力な機械的な外力 を印加すると，分子分散している濃度が増加して，言 い換えれば，一時的に過飽和になり，見かけの溶解度 の増加を引き起こす。

2. 水中において生成する油滴の大きさは，通常言われ ている油と水との界面張力の值よりもむしろ油の粘性 と密接に関係し, 粘性の大きい油の方が生成する油滴 の大きさは小さくなる。

3. 水中において生成した油滴は必然的に経時変化して 大きくなるが，そのプロセスには 2 通りある。一つ は，水に対する溶解度をほとんど無視できる油を用い た場合に観察されるプロセスで連続的な成長である。 二つ目は水に対する溶解度がある程度ある油，あるい は粘性の小さな油を用いた場合に観察されるプロセス で離散的に成長する。

4.これらの不安定な油滴に, 粘性が大きく, かつ, 相 互溶解性のない油を少量添加すると，それらの粒子径 は安定化されてあたかも粘性の高い油が界面活性剤の ような振る舞いをして，言い換えれば，“油が油を乳 
化する”興味深い現象を引き起こす。

5 . 通常のエマルションを調製する場合, 界面活性剂は 分散処理前あるいはその過程で添加されているが，油 滴表面上で形成された界面活性剂分子で構成される液 体膜は分散のための粉砕手段に対しても保護膜として 作用するため, 得られるエマルション滴は必ずしも小 さくならず，あるいは余計な外的エネルギーを必要と する。

したがって，乳化しようとする油の個性を十分に理解 した上で，界面活性剤が存在する通常のエマルションを 調製すれば界面活性剤の使用量は少なくて済み，また余 計な外的エネルギーも低減できるので，それは環境保全 にも寄与することになり得るものと考える。

何れにしても，これまで定性的展開の多かったエマル ションの世界をより定量的なものへと変化させていくた めには，より分子レベルでの検討が不可欠になるであろ )。

(受付： 2000 年 8 月 23 日, 受理： 2000 年 9 月 17 日)

\section{文献}

1) Evans, D. F. \& Wennersrrom, H. (1990) THE COLLOIDAL DOMAIN SECOND EDITION, Wiley-VCH, Inc., New York.

2) McClements, D. J. (1998) Food Emulsions: Practice and Techniques, CRC Press, Boca Raton, FL.

3) Hunter, R. J. (1986) Foundations of Colloid Science Vol. 1, Oxford University Press, Oxford.

4) Hiemenz, P. C. \& Rajagopalan, R. (1985) Principles of Colloid and Surface Chemistry, 3rd ed. Marcel Dekker: New York.

5) Davis, S. S. \& Smith, A. (1976) Theory Practice Emulsion Technol, Academic Press, London.

6) Weiss, J. \& McClements, D. J. (2000) Langmuir, 16, 2145.

7) Mukesh, D., Das, A. K. \& Ghosh, P. K. (1992) Langmuir, 8, 807 .

8) Bolzinger-Thevenin, M. A., Grossiord, J. L. \& Poelman, M. C. (1999) Langmuir, 15, 2307.

9) Strey, R. (1994) Colloid and Polymer Science, 272, 1005.

10) Bernheim-Groswasser, A., Tlusty, T., Safran, S. A. \& Talmon, Y. (1999) Langmuir, 15, 5448.

11) Sakai, H., Kawahara, H., Shimazaki, M. \& Abe, M. (1998) Langmuir, 14, 2208.

12）阿部正彦, (1998) フレグランスジャーナル， 1998-8, 29.
13）阿部正彦, (2000) “機能性化粧品 III”, 鈴木正人監修, p.316, シーエムシー.

14) Kamogawa, K. \& Abe, M. Encyclopedia of Surface and Colloid Science, Marcel Dekker, New York, in press.

15) Kamogawa, K., Sakai, T., Momozawa, N., Shimazaki, M., Enomura, M., Sakai, H. \& Abe, M. (1998) J. Jpn. Oil Chem. Soc., 47, 159.

16) Adamson, A. W. \& Gast, A. P. (1997) Physical Chemistry of Surfaces, John Wiley \& Sons, Inc.

17) Kamogawa, K. Matsumoto, M. Kobayashi, T. Sakai, T. Sakai, H. \& Abe, M. (1999) Langmuir, 15, 1913.

18) Kamogawa, K., Matsumoto, M., Kobayashi, T., Sakai, T., Sakai, H. \& Abe, M. under preparation.

19) Gopal, E. S. R. (1969) Emulsion Science, chapt. 1, Sherman, P. Ed., Academic Press, London.

20) Walstra, P. (1983) Formation of Emulsions, chapt. 2, In Encyclopedia of Emulsion Technology, Vol. 1. Bechner, P. Ed; Marcel Dekker, New York.

21) Kamogawa, K., Kuwayama, N., Sakai, T., Sakai, H. \& Abe, M. under preparation.

22) Graciaa, A., Morel, G., Saulner, P., Lachaise, J. \& Schechter, R. S. (1995) J. Colloid Interface Sci., 172, 131.

23) Schechter, R. S., Graciaa, A. \& Lachaise, J. (1998) J. Colloid Interface Sci., 204, 398.

24) Sakai, T., Kamogawa, K., Harusawa, F., Momozawa, N., Sakai, H. \& Abe M. to be submitted.

25) Derjaguin, B. V. \& Landau, L. D. (1941) Acta Physicochim., URSS, 14, 633.

26) Verwey, E. J. W. \& Overbeek, J. Th. G. (1948) Theory of the Stability of Lyophobic Colloids, Elsevier, Amsterdam.

27) Goodwin, J. W. \& Rhider, A. M. (1976) In Colloid and Interface Science", Vol. 4, Kerker, M., Ed., Academic Press, New York.

28) Buscall, R., Goodwin, J. W., Hawkins, M. W. \& Ottewill, R. H. (1982) J. Chem. Soc., Faraday Trans., 78, 2889.

29) Thomson, W. (Lord Kelvin), (1871) Proc. Roy. Soc., Edinburgh 7,63.

30) Kamogawa, K., Akatsuka, H., Matsumoto, M., Yokoyama, S., Sakai, T,. Sakai, H. \& Abe, M., Colloids and Surfaces A,; Physicochem, Eng. Aspects, in press.

31）島内武彦, (1980) 赤外吸収スペクトル解析法, 南江堂.

32) Lifshitz,I. M. \& Vslezov, V. (1961) J. Phys. Chem. Solids, $19,35$.

33) Taylor, P. (1998) Advances in Colloid and Interface Science, 75, 107.

34) Kabalnov, A. S. (1994) Langmuir, 10, 680. 


\title{
論 文 要 旨
}

\section{縲合諞文 光機能中心としてのポルフィリン二量体システム}

西岡琢哉 ${ }^{a}$. 有村隆志 ${ }^{a}$

a 工業技術院 物質工学工業技術研究所 COE 特別研究室（T 305-8565 茨城県つくば市東 1-1）

光合成反応中心では，スペシャルペアと呼ばれるポルフィリン誘導体の二量体が，電荷分離の初期過程で重要な役 割を果たしている。この二量体の性質の解明は, 人工光合成反応や光エネルギー変換デバイス開発において極めて重 要となる。これまでに, 数多くのポルフィリン二量体がスペシャルペアのモデル化合物として合成され, その光物性 が研究されてきた。また，ポルフィリン二量体は，分子認識にも応用されるようになっている。本稿では，ポルフィ リン二量体システムにおける電子移動および分子認識に関する最近の研究を中心に紹介する。

(連絡者：有村隆志）Vol.1, No.1.9（2001）

\section{䌊合輪文 糖脂質系バイオサーファクタントの新しい展開 一生理活性物質から省エネルギー材料まで一}

\author{
北本 大 $^{\mathrm{a}}$
}

a 通産省工業技術院 物質工学工業技術研究所（テ 305-8565 茨城県つくば市東 1-1）

微生物により生産されるバイオサーファクタント（BS）は, 合成界面活性剤に比べて, 生体および環境適合性を始 め多くの優れた特性を有している。BS の研究は石油利用技術に端を発しているが, 現在では, 食品, 化粧品, 医薬品 産業から省エネルギー, 環境保全技術まで, 幅広い分野への応用が検討されている。特に, 糖脂質系 BS は, 再生可能 資源からの生産性, 生化学的機能の多面性で優位にあり, 今後最も発展が期待されている BSである。マンノシルエリ スリトールリピドは, 酵母の生産する糖脂質系 BS の一つであり, 優れた界面化学的特性（表面・界面張力低下能, べ シクル集合能）を示すばかりでなく，特異な抗微生物活性，紏胞分化誘導活性も有している。最近，この糖脂質が氷 蓄熱システムにおいて，氷粒子に対して優れた凝集抑制効果を示すことが判り，BS の新たな技術分野への展開が期待 されている。

（連絡者：北本大）Vol.1, No.1.17（2001）

\section{総合論文 界面活性剤無添加系エマルションの新しい展開}

酒井俊 郎 ${ }^{a}$. 加茂川恵司 ${ }^{b}$. 酒井秀樹 $a b$. 阿部正彦 ${ }^{a b}$
a 東京理科大学 理工学部（广 278-8510 千葉県野田市山崎 2641）
b 東京理科大学 界面科学研究所（广 278-8510 千葉県野田市山崎 2641）

もし，界面活性剤を添加することなくエマルションやマイクロエマルションのような微細粒子が調製できるならば， その液滴は高い疎水性を有する内部とクリアーかつ疎水性の高い界面を持ち，従来のマイクロエマルション滴とは異 なった物性を示すことが予想される。サーファクタントフリーエマルションは，界面活性剤などの安定化剤が存在し ないため熱力学的に不安定であり，過飽和溶質分子による核形成や水中への有機溶媒（溶質）の強制的な分散によっ て過渡的に調製される。サーファクタントフリーエマルションは，最もシンプルな液／液分散系であるため，エマル ションの成長過程や安定性機構，液滴サイズの決定因子などの解明に有効であると考えられる。この総合論文では， 油滴の離散的な粒子径分布，微細粒子の形成（あるいは分散安定性）と油の粘度（あるいは蒸気圧）との関係， S ク ラスとMクラス油滴の成長過程の違い，油分子自身の構造の分散安定性に及ぼす影響，第二油の混合のよる油滴の分 散安定性などについて述べる。

(連絡者：阿部正彦）Vol.1, No.1.33（2001） 